\title{
CuSCN as the Back Contact for Efficient ZMO/CdTe Solar Cells
}

\author{
Deng-Bing Li ${ }^{1}{ }^{\oplus}$, Zhaoning Song ${ }^{1} \mathbb{(}$, Sandip S. Bista ${ }^{1}{ }^{\circledR}$, Fadhil K. Alfadhili ${ }^{1}$, \\ Rasha A. Awni ${ }^{1}{ }^{\circledR}$, Niraj Shrestha ${ }^{1}$, DeMilt Rhiannon ${ }^{2}$, Adam B. Phillips ${ }^{1}{ }^{\mathbb{D}}$, Michael J. Heben ${ }^{1}$, \\ Randy J. Ellingson ${ }^{1}$, Feng Yan ${ }^{3}$ (D) and Yanfa Yan ${ }^{1, *}$ \\ 1 Department of Physics and Astronomy, and Wright Center for Photovoltaics Innovation and \\ Commercialization (PVIC), University of Toledo, Toledo, OH 43606, USA; dengbing.li@utoledo.edu (D.-B.L.); \\ zhaoning.song@utoledo.edu (Z.S.); sandip.bista@rockets.utoledo.edu (S.S.B.); \\ fadhil.alfadhili@rockets.utoledo.edu (F.K.A.); rasha.awni@rockets.utoledo.edu (R.A.A.); \\ niraj.shrestha@rockets.utoledo.edu (N.S.); adam.phillips@utoledo.edu (A.B.P.); \\ michael.heben@utoledo.edu (M.J.H.); randy.ellingson@utoledo.edu (R.J.E.) \\ 2 Ottawa Hills Junior/senior high school, Ottawa Hills Local Schools, Ottawa Hills, OH 43606, USA; \\ rdemilt20@ohschools.org \\ 3 Department of Metallurgical and Materials Engineering, The University of Alabama, \\ Tuscaloosa, AL 35487, USA; fyan@eng.ua.edu \\ * Correspondence: yanfa.yan@utoledo.edu
}

Received: 21 March 2020; Accepted: 21 April 2020; Published: 24 April 2020

\begin{abstract}
The replacement of traditional CdS with zinc magnesium oxide (ZMO) has been demonstrated as being helpful to boost power conversion efficiency of cadmium telluride $(\mathrm{CdTe})$ solar cells to over $18 \%$, due to the reduced interface recombination and parasitic light absorption by the buffer layer. However, due to the atmosphere sensitivity of ZMO film, the post treatments of $\mathrm{ZMO} / \mathrm{CdTe}$ stacks, including $\mathrm{CdCl}_{2}$ treatment, back contact deposition, etc., which are critical for high-performance CdTe solar cells became crucial challenges. To realize the full potential of the ZMO buffer layer, plenty of investigations need to be accomplished. Here, copper thiocyanate (CuSCN) is demonstrated to be a suitable back-contact material with multi-advantages for $\mathrm{ZMO} / \mathrm{CdTe}$ solar cells. Particularly, ammonium hydroxide as the solvent for CuSCN deposition shows no detrimental impact on the ZMO layer during the post heat treatment. The post annealing temperature as well as the thickness of CuSCN films are investigated. Finally, a champion power conversion efficiency of $16.7 \%$ is achieved with an open-circuit voltage of $0.857 \mathrm{~V}$, a short-circuit current density of $26.2 \mathrm{~mA} / \mathrm{cm}^{2}$, and a fill factor of $74.0 \%$.
\end{abstract}

Keywords: copper thiocyanate; CuSCN; CdTe; zinc magnesium oxide

\section{Introduction}

In the past few years, cadmium telluride ( $\mathrm{CdTe}$ ) solar cells have experienced a rapid performance improvement, with certified record power conversion efficiencies (PCEs) reaching $22.1 \%$ for cells and over $18.6 \%$ for modules [1,2]. Benefitting from its multi-advantages, including low manufacturing costs, a suitable bandgap, high light absorption coefficients, and, thus, a high theoretical efficiency of over $30 \%$ [3], CdTe technology currently dominates the thin-film photovoltaic market. Despite the success in commercialization, it is still challenging to reproduce the record efficiency of CdTe solar cells in research institutes over the world. The efficiency loss is mainly caused by the low p-type conductivity and high electron affinity of CdTe films [4,5], which make them crucial challenges to form a good ohmic contact between CdTe and a metal electrode. The existence of non-ohmic contact produces a back barrier and increases the recombination at the interface of CdTe and the metal electrode, significantly 
limiting the open-circuit voltage $\left(\mathrm{V}_{\mathrm{OC}}\right)$ and fill factor $(\mathrm{FF})$ of CdTe solar cells. To overcome this issue, copper $(\mathrm{Cu})$ is commonly used to improve the conductivity of $\mathrm{CdTe}$ and reduce the back-barrier height. However, the concern of long-time stability, due to the ease of $\mathrm{Cu}$ migration, inhibits its commercial applications [6]. Group V element (e.g., As and P) doping, as an alternative to $\mathrm{Cu}$ doping for the desired long-time stability, has recently attracted intensive investigations. [7-9] However, limited by the high capital costs of the equipment used for the in-situ doping and low effective doping level for the ex situ doping (due to aggregations at grain boundaries), group V doping has not been widely used by the researchers $[7,10]$.

Copper thiocyanate (CuSCN), a low-cost and solution-processable material with a high work function of $5.3 \mathrm{eV}$ [11], has been widely used in dye-sensitized and organic-inorganic perovskite solar cells as the hole transport layer to facilitate the carrier extraction [12-14]. In 2015, CuSCN was first reported by our group as copper source instead of metallic copper in CdTe solar cells, which delivers an impressive improvement in $\mathrm{V}_{\mathrm{OC}}$. [11] Recently, CuSCN was successfully used in CdSeTe solar cells, showing an impressive $\mathrm{V}_{\mathrm{OC}}$ of around $0.860 \mathrm{~V}$ and an efficiency of $\sim 17.0 \%$, which makes it a promising back-contact for CdTe solar cells [15]. In this work, the application of solution processed CuSCN as the back contact in pure CdTe solar cells with zinc magnesium oxide (ZMO) as the buffer layer is investigated. ZMO is an emerging buffer layer in CdTe solar cells and helps boost their device performance, due to the reduction in interface recombination at the buffer layer/CdTe interface and parasitic light absorption by the buffer layer [16]. Recently, PCEs of $19.1 \%$ and $18.6 \%$ for CdSeTe and pure CdTe solar cells, respectively, with ZMO buffer layers have been demonstrated [17]. However, it has also been reported that an oxygen-free atmosphere is required for $\mathrm{ZMO} / \mathrm{CdTe}$ devices during the CdTe deposition, as well as the post treatments; otherwise, the devices show poor performances, due to the presence of severe S-kinks [18,19]. Additionally, it is reported that the finished ZMO/CdTe devices degrade rapidly when exposing to the ambient atmosphere, likely due to the reaction between water and the ZMO film [20]. All of these suggest that the post treatment of ZMO/CdTe solar cells should be done with great alertness.

Till now, there are only few reports on the optimization of post treatments, especially the back-contact treatment for $\mathrm{ZMO} / \mathrm{CdTe}$ solar cells. During the optimization processes, we have tried different hole transport materials (e.g., metallic $\mathrm{Cu}$ [21], carbon paste [22]) and back surface treatments (e.g., hydroiodic (HI) solution [23], Br methanol solution [24] and MAI solution [25] etching), which have been demonstrated effective in improving the $\mathrm{CdS} / \mathrm{CdTe}$ device performance. However, most of these processes show adverse effects on the $\mathrm{ZMO} / \mathrm{CdTe}$ devices, probably caused by the degradation of the ZMO films during the depositions or treatments. In this work, CuSCN dissolved in ammonium hydroxide solution (30 wt.\% in water) was used to deposit $\mathrm{CuSCN}$ as a back contact for $\mathrm{ZMO} / \mathrm{CdTe}$ solar cells. $\mathrm{ZMO} / \mathrm{CdTe}$ devices with metallic $\mathrm{Cu}$ doping were used as a reference. Through the optimization of post annealing temperature and the CuSCN film thickness, the solar cells based on the $\mathrm{ZMO} / \mathrm{CdTe} / \mathrm{CuSCN}$ stack show a high PCE of $16.7 \%$, with a $\mathrm{V}_{\mathrm{OC}}$ of $0.857 \mathrm{~V}$, a short-circuit current density (JSC) of $26.2 \mathrm{~mA} / \mathrm{cm}^{2}$, and a FF of $74.0 \%$. The result demonstrates that $\mathrm{CuSCN}$ is a robust hole transport material for CdTe solar cells with $\mathrm{ZMO}$ as the buffer layer.

\section{Materials and Methods}

The Schematic illustration of technological steps and investigation design in this work is shown in Figure S1. The devices in this work were fabricated according to our previous report [18]. Fluorine doped tin oxide coated glass (FTO, TEC12; Pilkington NA, Toledo, OH, USA) is used as the substrate after thermal ultrasonic cleaning in Micro-90 detergent (St. Louis, MO, USA) and deionized water at $70{ }^{\circ} \mathrm{C}$. A $80 \mathrm{~nm}$ ZMO film was then deposited on the cleaned FTO glass, using a radio frequency sputter system at ambient temperature. The deposition was conducted at 6 mTorr pressure under a mix gas flow of $3 \%$ oxygen and $97 \%$ helium at a $25 \mathrm{~W}$ sputtering power, using a 2-inch ZMO target with $8 \mathrm{wt} . \%$ magnesium oxide. Then, a $\sim 3.5 \mu \mathrm{m}$ CdTe film was deposited in a close-space sublimation (CSS) chamber, with the source temperature of $560{ }^{\circ} \mathrm{C}$, the substrate temperature of $495^{\circ} \mathrm{C}$, and a 
chamber pressure of 1 Torr. The $\mathrm{CdCl}_{2}$ activation treatment was carried out by drop-casting a saturated $\mathrm{CdCl}_{2}$ in methanol solution on the CdTe surface, followed with drying naturally and annealing at $420{ }^{\circ} \mathrm{C}$ for $20 \mathrm{~min}$ at 400 Torr with a $500 \mathrm{sccm}$ helium gas flow. After cooling down, the CdTe film was rinsed by methanol thoroughly to clean the excess $\mathrm{CdCl}_{2}$. The $\mathrm{CuSCN}$ solution was prepared by dissolving the CuSCN powder in ammonium hydroxide (30 wt.\%), or diethyl sulfide with different concentrations $(2 \mathrm{mg} / \mathrm{mL}$ and $10 \mathrm{mg} / \mathrm{mL})$, and then stirring at room temperature for more than $5 \mathrm{~h}$ to facilitate the dissolution. Then, the solution was filtered using a $0.45 \mu \mathrm{m}$ pore size PTFE filter for the later use. The thickness of CuSCN film was tuned by varying the spin coating speed (2000 rpm and $6000 \mathrm{rpm})$, and the solution concentration $(2 \mathrm{mg} / \mathrm{mL}$ and $10 \mathrm{mg} / \mathrm{mL})$. After the CuSCN deposition, the film was heated in our CSS chamber to different temperatures $\left(140{ }^{\circ} \mathrm{C}, 160{ }^{\circ} \mathrm{C}, 180{ }^{\circ} \mathrm{C}\right)$ at a ramp rate of $\sim 35^{\circ} \mathrm{C} / \mathrm{min}$ with a $500 \mathrm{sccm}$ helium flow under ambient pressure. After cooling down naturally, a $40 \mathrm{~nm}$ of thick gold was deposited via a shadow mask with an individual area of $0.08 \mathrm{~cm}^{2}$ in a thermal evaporator. The optimized reference $\mathrm{ZMO} / \mathrm{CdTe}$ devices with evaporated $\mathrm{Cu}$ metal were fabricated in the same procedure, except evaporating a $3 \mathrm{~nm} \mathrm{Cu}$ and $40 \mathrm{~nm}$ Au bilayer then annealing in ambient pressure at $200{ }^{\circ} \mathrm{C}$ for $20 \mathrm{~min}$. The samples for the photoluminescence (PL) measurements were fabricated by depositing $2.5 \mu \mathrm{m}$ CdTe films followed with the standard $\mathrm{CdCl}_{2}$ treatment and the CuSCN or metallic Cu treatment, respectively. All the completed devices described above are listed in Table 1.

Table 1. Details of all devices fabricated in this work. Note that the buffer layer, $\mathrm{CdTe}$ layer, and $\mathrm{CdCl}_{2}$ treatment are identical for all the devices as mentioned above.

\begin{tabular}{ccccc}
\hline Devices & Cu Source & Solvent & CuSCN Deposition & Activation Procedure \\
\hline CdTe-Cu & Cu metal & N/A & TE, 3 nm & $200{ }^{\circ} \mathrm{C}$ for $20 \mathrm{~min}$ \\
CuSCN-140 & CuSCN & NH & SP, $10 \mathrm{mg} / \mathrm{mL}-6000 \mathrm{rpm}$ & $140^{\circ} \mathrm{C}$ for $0 \mathrm{~min}$ \\
CuSCN-160 & CuSCN & $\mathrm{NH}$ & $\mathrm{SP}, 10 \mathrm{mg} / \mathrm{mL}-6000 \mathrm{rpm}$ & $160^{\circ} \mathrm{C}$ for $0 \mathrm{~min}$ \\
CuSCN-180 & $\mathrm{CuSCN}$ & $\mathrm{NH}$ & $\mathrm{SP}, 10 \mathrm{mg} / \mathrm{mL}-6000 \mathrm{rpm}$ & $180^{\circ} \mathrm{C}$ for $0 \mathrm{~min}$ \\
$2 \mathrm{mg} / \mathrm{mL}-6000 \mathrm{rpm}$ & $\mathrm{CuSCN}$ & $\mathrm{NH}$ & $\mathrm{SP}, 2 \mathrm{mg} / \mathrm{mL}-6000 \mathrm{rpm}$ & $160^{\circ} \mathrm{C}$ for $0 \mathrm{~min}$ \\
$2 \mathrm{mg} / \mathrm{mL}-2000 \mathrm{rpm}$ & $\mathrm{CuSCN}$ & $\mathrm{NH}$ & $\mathrm{SP}, 2 \mathrm{mg} / \mathrm{mL}-2000 \mathrm{rpm}$ & $160^{\circ} \mathrm{C}$ for $0 \mathrm{~min}$ \\
$8 \mathrm{mg} / \mathrm{mL}-6000 \mathrm{rpm}$ & $\mathrm{CuSCN}$ & $\mathrm{NH}$ & $\mathrm{SP}, 10 \mathrm{mg} / \mathrm{mL}-6000 \mathrm{rpm}$ & $160^{\circ} \mathrm{C}$ for $0 \mathrm{~min}$ \\
$8 \mathrm{mg} / \mathrm{mL}-2000 \mathrm{rpm}$ & $\mathrm{CuSCN}$ & $\mathrm{NH}$ & $\mathrm{SP}, 10 \mathrm{mg} / \mathrm{mL}-2000 \mathrm{rpm}$ & $160^{\circ} \mathrm{C}$ for $0 \mathrm{~min}$ \\
diethyl sulfide & $\mathrm{CuSCN}$ & $\mathrm{DS}$ & $\mathrm{SP}, 10 \mathrm{mg} / \mathrm{mL}-2000 \mathrm{rpm}$ & $160^{\circ} \mathrm{C}$ for $0 \mathrm{~min}$ \\
\hline
\end{tabular}

Note: NH for ammonium hydroxide; DS for diethyl sulfide; TE for thermal evaporation; SP for spin coating.

The device bandgap diagram simulation was performed using the solar cell capacitance simulator (SACPS) [26], and the parameters were used according to our previous publication [18]. Steady-state photoluminescence (PL) measurement was performed utilizing a $532 \mathrm{~nm}$ continuous wave laser at $\sim 5 \mathrm{~W} \cdot \mathrm{cm}^{-2}$. Samples were excited through the film side. PL signal was detected by a symphony-II Si (CCD) detector (Horiba Scientific, NJ, USA) after a Horiba iHR320 monochromator (Horiba Scientific). The morphological microstructures of the CdTe films were characterized by a nanoscope atomic force microscope (Troy, MI, USA). The solar cell performance was characterized by measuring the current density-voltage (J-V) curves under AM1.5G illumination using a solar simulator (PV Measurements Inc. Point Roberts, WA, USA) and a source meter (Keithley 2400, Beaverton, OR USA). External quantum efficiency (EQE) spectra were performed on a QE system (PV Measurements, Beaverton, OR, USA). Temperature-dependent current-voltage (J-V-T) measurements were performed in a closed-cycle helium cryostat, with a tungsten lamp as a light source, and the temperature was varied from 200 to $310 \mathrm{~K}$, with a step size of $10 \mathrm{~K}$. An inhouse designed LabVIEW (National Instruments, Inc. Beaverton, OR, USA) control program was used to operate the temperature controller, and the Keithley 2400 source-meter for current and voltage data acquisition.

\section{Results and Discussion}

Figure 1a shows the simulated bandgap diagram of ZMO/CdTe solar cells, with CuSCN as the hole transport layer. The valence band offset between CdTe and CuSCN is favorable for the holes to be extracted from the CdTe layer. Additionally, the low electron affinity with respect to CdTe can 
favorably repel electrons and prevent them from diffusing into the back electrode. This CdTe/CuSCN heterostructure can eliminate the carrier recombination on the rear side of CdTe, consequently enhancing carrier collection efficiency. The steady-state PL was carried out to further confirm the carrier extraction efficiency (Figure $1 \mathrm{~b}$ ). The CdTe-Cu reference sample exhibits a high intense PL emission peak, centered at $1.50 \mathrm{eV}$. With the presence of the $\mathrm{CuSCN}$ film, the PL emission peak shows pronounced intensity quenching, suggesting strong carrier extraction from the CdTe into the CuSCN. Atomic force microscopy (AFM) measurements were performed to confirm the uniformity of CuSCN film deposited on the CdTe films. The AFM image of bare CdTe film as shown in Figure 1c, exhibits a uniform grain size of $\sim 2 \mu \mathrm{m}$, with a root mean squared (RMS) roughness of $147 \mathrm{~nm}$. With the spin-coated CuSCN layer (Figure 1d), the RMS is slightly decreased to $139 \mathrm{~nm}$, indicating a smooth coating of CuSCN particles.
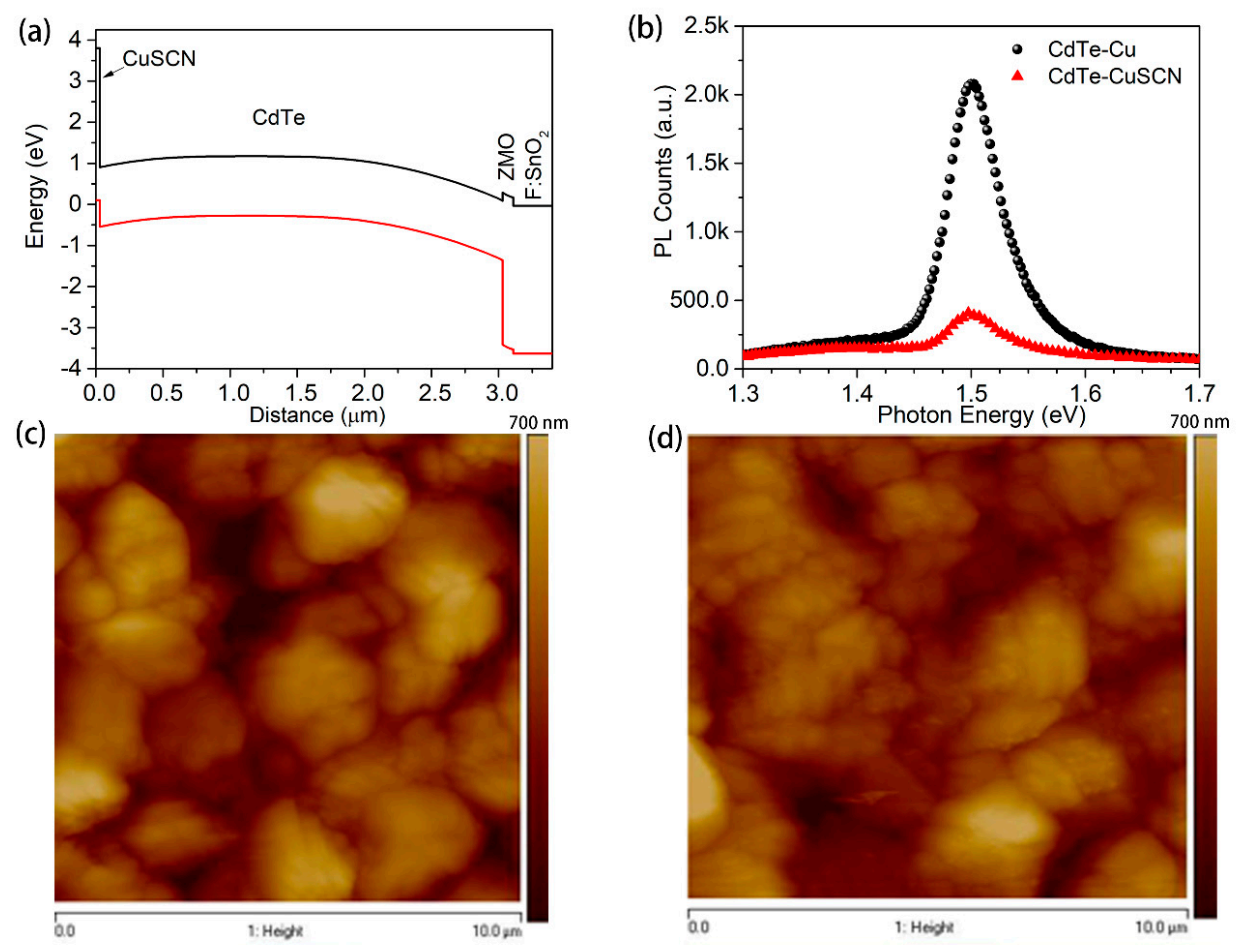

Figure 1. (a) Solar cell capacitance simulator (SCAPS) modeling determined band diagram for the device with a structure of fluorine doped tin oxide coated glass (FTO)/zinc magnesium oxide $(\mathrm{ZMO}) / \mathrm{cadmium}$ telluride (CdTe)/copper thiocyanate (CuSCN)/Au. (b) Steady-state PL spectra of $\mathrm{CdTe}-\mathrm{Cu}$ and $\mathrm{CdTe}-\mathrm{CuSCN}$ stacks deposited on soda lime glass substrates. Atomic force microscopy images showing the surface morphologies of (c) a bare CdTe film and (d) a CdTe film deposited with CuSCN.

The diffusion of $\mathrm{Cu}$ into the $\mathrm{CdTe}$ film is a necessary step to improve the ohmic contact between CdTe and the metal electrode. In CdTe/CuSCN stacks, the diffusion of $\mathrm{Cu}$ from CuSCN into CdTe not only increases the p-type conductivity of $\mathrm{CdTe}$, but also leaves $\mathrm{Cu}$ vacancies in the CuSCN layer, which helps to further increase the work function of CuSCN [27]. To optimize the CuSCN layer, the impact of the annealing temperature of CuSCN was investigated. As shown in Figure 2, the ZMO/CdTe devices with the metallic $\mathrm{Cu}$ (named $\mathrm{CdTe}-\mathrm{Cu}$ hereafter) was used as a control to compare with the $\mathrm{ZMO} / \mathrm{CdTe}$ devices with a $30 \mathrm{~nm}$ CuSCN layer. The devices with the CuSCN back contact were annealed at different temperatures $\left(140{ }^{\circ} \mathrm{C}, 160{ }^{\circ} \mathrm{C}\right.$, and $180^{\circ} \mathrm{C}$, named CuSCN-140, CuSCN-160, and CuSCN-180, respectively). With the presence of $\mathrm{CuSCN}$, the devices show overall higher performances than the control devices with the metallic $\mathrm{Cu}$ in all the PV parameters. The inferior performance of the reference devices is likely due to the over-diffusion of $\mathrm{Cu}$ through $\mathrm{CdTe}$ into the ZMO film, which significantly 
reduces the conductivity of ZMO film by several orders [28-30]. We have tried to reduce the annealing temperature and time for the reference devices to reduce the diffusion length of $\mathrm{Cu}$. However, the devices show even worse performances, probably due to the insufficient $\mathrm{Cu}$ diffusion. In comparison, $\mathrm{CdTe}-\mathrm{CuSCN}$ devices annealed at $140{ }^{\circ} \mathrm{C}$ for a short duration (a few seconds) outperform the CdTe-Cu devices annealed at $200{ }^{\circ} \mathrm{C}$ for $20 \mathrm{~min}$. This result indicates the possibility of reducing the adverse effect caused by the $\mathrm{Cu}$ over diffusion through performing $\mathrm{Cu}$ annealing at a lower temperature and a shorter holding time. Through lower temperature and shorter time annealing, the Cu diffused into CdTe can be easily confined on the rear side close to the back electrode. The predictable sharp copper concentration profile from the back surface to the bulk not only guarantees a proper $\mathrm{Cu}$ concentration on the rear side of CdTe to improve the ohmic contact, but also helps to reduce the $\mathrm{Cu}$ related deep trap states in the bulk and front interface caused by excess $\mathrm{Cu}$ concentrations [31-33]. The proper $\mathrm{Cu}$ doping control through our CuSCN treatment can assist to enhance outstanding performance for the CdTe-CuSCN devices.
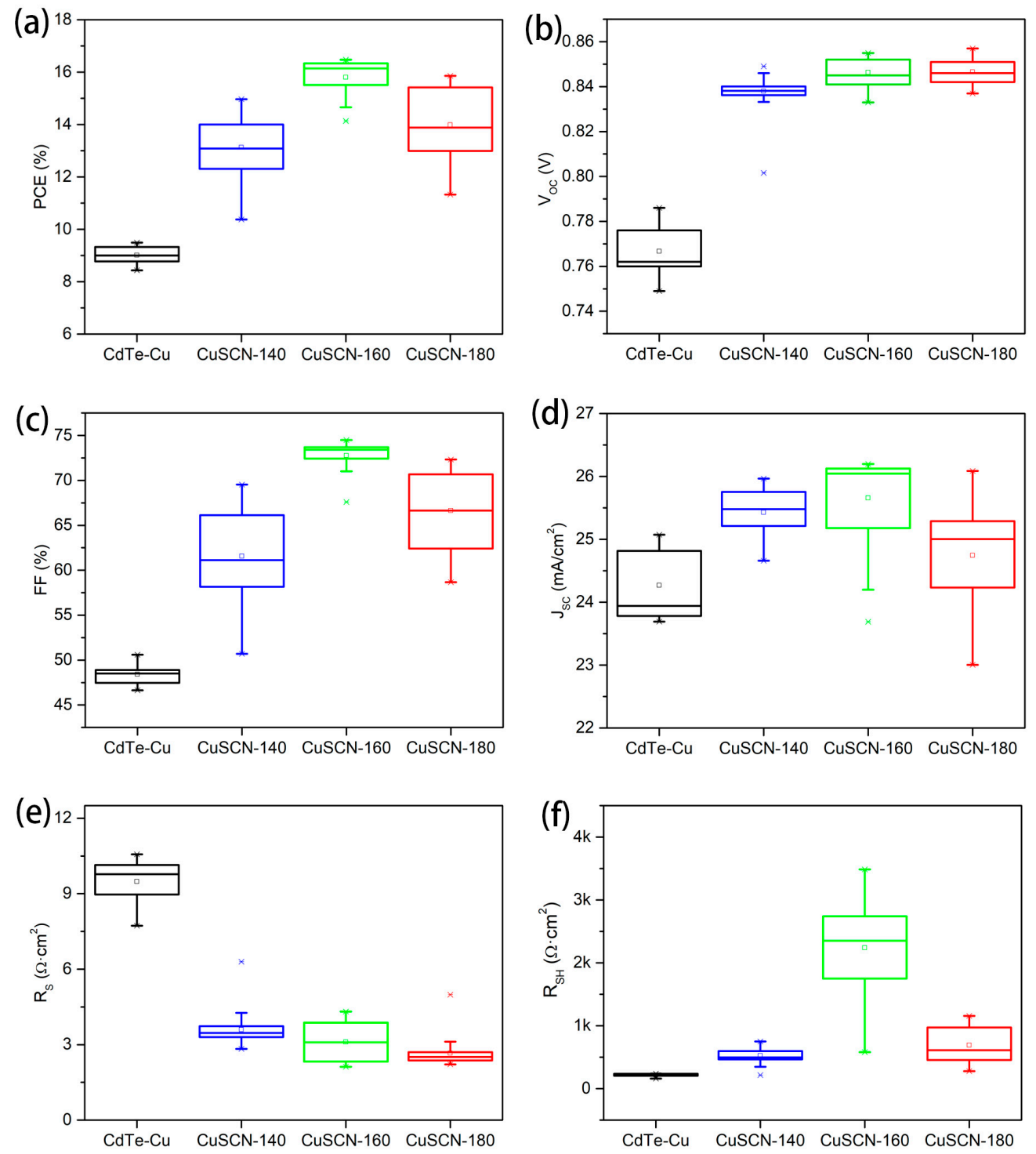

Figure 2. Statistical results for MZO/CdTe solar cell performances of (a) PCE, (b) $\mathrm{V}_{\mathrm{OC}}$, (c) FF, (d) JSC, (e) series resistance $\left(R_{S}\right)$, and (f) shunt resistance $\left(R_{S H}\right)$ with metallic $\mathrm{Cu}$ and spin-coated CuSCN annealed at different temperatures. 
By increasing the annealing temperature, the mean $\mathrm{V}_{\mathrm{OC}}$ gradually increases from $0.838 \mathrm{~V}$ for CuSCN-140 to $0.847 \mathrm{~V}$ for CuSCN-180. The devices annealed at $160^{\circ} \mathrm{C}$ deliver the best performance due to the largely improved FF (74.6\%), compared to those devices annealed at lower or higher temperatures. This is mainly attributed to the higher hole concentration in CdTe bulk benefited from the proper copper diffusion. Higher hole concentration can boost a higher build-in potential $\left(\mathrm{V}_{\mathrm{bi}}\right)$ and lead to less recombination in the depletion region and at the front interface, thereby resulting in larger FF, which can be further confirmed through the improvement of the shunt resistance $\left(\mathrm{R}_{\mathrm{SH}}\right)$. Accompanied with the variation of the annealing temperature, the $\mathrm{R}_{\mathrm{SH}}$ increases from the mean value $490 \Omega \mathrm{cm}^{2}$ for CuSCN-140 to $2360 \Omega \mathrm{cm}^{2}$ for CuSCN-160. When the annealing temperature is further increased to $180{ }^{\circ} \mathrm{C}$, the mean $\mathrm{R}_{\mathrm{SH}}$ decreases to $610 \Omega \mathrm{cm}^{2}$, due to the excess $\mathrm{Cu}$ in the CdTe bulk and at the front interface. As the annealing temperature increases, the series resistance $\left(R_{S}\right)$ decreases slightly from $3.50 \Omega \mathrm{cm}^{2}$ in CuSCN-140 to $3.07 \Omega \mathrm{cm}^{2}$ in CuSCN-160, and further to $2.51 \Omega \mathrm{cm}^{2}$ in CuSCN-180. The $\mathrm{JSC}_{\mathrm{SC}}$ also shows similar trend as the $\mathrm{FF}$ and the shunt resistance at different annealing temperatures.

The J-V curves of the best cells of CdTe-Cu and CdTe-CuSCN are plotted in Figure 3a, and more detailed parameters are displayed in Table 2. Comparing to the CdTe-Cu device, the CdTe-CuSCN device shows a higher JSC value, partially due to the reduced recombination at the depletion region and front interface as discussed above. Another reason is the reduced carrier recombination at the back interface between CdTe and the metal electrode, which can be confirmed by the absence of severe roll-over and cross-over effects in the J-V curves at high forward bias for the CdTe-CuSCN devices. The roll-over effect is commonly an indicator of insufficient copper doping on the rear side of CdTe film [34-36], and the cross-over effect is due to photoconductivity in the buffer layer which could be caused by the aggregation of copper in the buffer layer. [37] For this sake, the CdTe-Cu device delivers an efficiency of $9.49 \%$, with $\mathrm{V}_{\mathrm{OC}}$ of $0.786 \mathrm{~V}$, JSC of $24.8 \mathrm{~mA} / \mathrm{cm}^{2}$, and FF of $48.7 \%$. In contrast, all the CdTe-CuSCN devices show the absence of the roll-over and cross-over effects at forward bias, indicating lower back-barrier heights, and less $\mathrm{Cu}$ aggregation at the front interface. Thus, the CdTe-CuSCN devices promise higher FF values $(69.1 \%$ for the CuSCN-140, $74.0 \%$ for the CuSCN-160, and 71.4\% for the CuSCN-180). Benefitting from the significantly improved FF, the CuSCN-160 device delivers the best efficiency of $16.5 \%$ with $\mathrm{V}_{\mathrm{OC}}$ of $0.850 \mathrm{~V}$, JSC of $26.2 \mathrm{~mA} / \mathrm{cm}^{2}$ and FF of $74.0 \%$. External quantum efficiency (EQE) curves were measured to examine the carrier extraction properties for all the devices. As shown in Figure 3b, all the devices show the overlapped curves in short wavelength below $400 \mathrm{~nm}$ due to the parasitic absorption of ZMO films. Between 500 to $800 \mathrm{~nm}$, the CdTe-Cu shows the lowest quantum efficiency, compared to the CuSCN ones. The deviation enlarged gradually as the wavelength increases, indicating a larger difference in the recombination properties at the CdTe and metal electrode interface. This can be attributed to two primary reasons: one is that the larger back-barrier height in $\mathrm{CdTe}-\mathrm{Cu}$ for the hole extraction, and the other one is that the high conduction band offset between CdTe and CuSCN, which can reflect the unfavorable electron diffusion into the CuSCN layer, and thereby suppress the recombination at the back interface. This is consistent with the result of PL quenching for the CdTe/CuSCN film stack. For the CdTe-CuSCN devices annealed at various temperatures, the variation in the quantum efficiency is mainly located at the long wavelengths, probably due to the difference in the $\mathrm{Cu}$ concentration at the back surface of CdTe. At higher temperatures, more $\mathrm{Cu}$ in the $\mathrm{CuSCN}$ layer can diffuse into CdTe. The CuSCN-160 device shows the highest quantum efficiency at long wavelengths, indicating the lowest back barrier height, which can be further confirmed in the temperature dependent $\mathrm{J}-\mathrm{V}$ measurement, described in the later section. When the annealing temperature is further increased to $180{ }^{\circ} \mathrm{C}$, the $\mathrm{Cu}$ concentration at back side is too high, and the interstitial compensation defects $\mathrm{Cu}_{\mathrm{i}}$, instead of substitutional acceptor defects $\mathrm{Cu}_{\mathrm{Cd}}$ become dominant, and the back barrier height increases, causing lower quantum efficiencies at long wavelengths for CuSCN-180. Overall, the CuSCN-160 device delivers the highest integrated current density of $25.5 \mathrm{~mA} / \mathrm{cm}^{2}$, with quantum efficiency over $85 \%$ in the whole wavelength range, and the highest value of $88.0 \%$ at $605 \mathrm{~nm}$, showing decent carrier transport and extraction properties. 

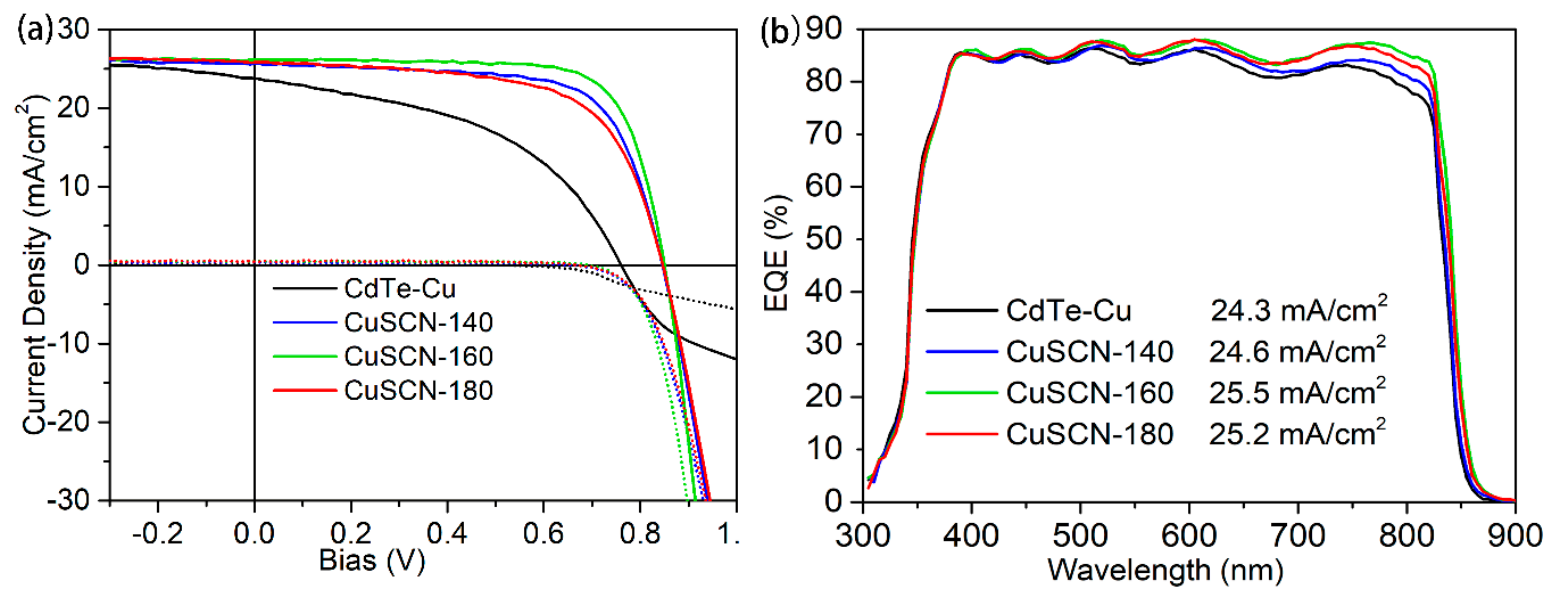

Figure 3. (a) Current density-voltage (J-V) and (b) external quantum efficiency (EQE) curves for the best devices with different back-contact treatment: evaporated $\mathrm{Cu}$ metal and spin-coated CuSCN with different annealing temperatures.

Table 2. Device performance of the best cells in CdTe-Cu and CdTe-CuSCN, annealed at different temperatures.

\begin{tabular}{ccccccc}
\hline Samples & $\mathbf{V}_{\mathbf{O C}}(\mathbf{V})$ & $\mathbf{J}_{\mathbf{S C}}\left(\mathbf{m A} / \mathbf{c m}^{\mathbf{2}}\right)$ & FF $\mathbf{\%})$ & Efficiency $\mathbf{( \% )}$ & $\mathbf{R}_{\mathbf{S}}\left(\boldsymbol{\Omega} \mathbf{~ c m}^{\mathbf{2}}\right)$ & $\mathbf{R}_{\mathbf{S H}}\left(\boldsymbol{\Omega} \mathbf{~ c m}^{2}\right)$ \\
\hline CdTe-Cu & 0.786 & 24.8 & 48.7 & 9.49 & 9.78 & 239 \\
CuSCN-140 & 0.836 & 25.9 & 69.1 & 15.0 & 2.95 & 734 \\
CuSCN-160 & 0.850 & 26.2 & 74.0 & 16.5 & 2.70 & 2580 \\
CuSCN-180 & 0.851 & 26.1 & 71.4 & 15.9 & 2.45 & 1140 \\
\hline
\end{tabular}

Due to the high resistivity of CuSCN, the thickness of CuSCN layer is critical for better carrier extraction efficiency. CdTe devices with different $\mathrm{CuSCN}$ thicknesses are fabricated using CuSCN solutions with different concentrations ( 2 and $10 \mathrm{mg} / \mathrm{mL}$ ) and spin-coating speeds (2000 and $6000 \mathrm{rpm}$ ), which are named $2 \mathrm{mg} / \mathrm{mL}-6000 \mathrm{rpm}, 2 \mathrm{mg} / \mathrm{mL}-2000 \mathrm{rpm}, 10 \mathrm{mg} / \mathrm{mL}-6000 \mathrm{rpm}$, and $10 \mathrm{mg} / \mathrm{mL}-2000 \mathrm{rpm}$, respectively. We tried to measure the CuSCN film thicknesses with different deposition parameters through scanning electron microscopy (SEM) measurements. Unfortunately, the CuSCN films are too thin (less than $30 \mathrm{~nm}$ ) to be accurately measured through SEM images. The cross-sectional SEM images of the whole devices with the thickest CuSCN film deposited at $2000 \mathrm{rpm}$ using $10 \mathrm{mg} / \mathrm{mL}$ CuSCN solution were shown in Figure S2, from which we can know the CuSCN film thickness is about $30 \mathrm{~nm}$, and the others should be thinner than $30 \mathrm{~nm}$. Based on spin-coating features, the thickness of the CuSCN films should rank as $2 \mathrm{mg} / \mathrm{mL}-6000 \mathrm{rpm}<2 \mathrm{mg} / \mathrm{mL}-2000 \mathrm{rpm}<10 \mathrm{mg} / \mathrm{mL}-6000 \mathrm{rpm}<$ $10 \mathrm{mg} / \mathrm{mL}-2000 \mathrm{rpm}$, which can be further confirmed by the gradual change of device performance. As shown in Figure 4, the $\mathrm{V}_{\mathrm{OC}}$ increases gradually as the thickness of CuSCN increases. This can be attributed to the increase of CuSCN film thickness, which supplies more $\mathrm{Cu}$ for the diffusion during the annealing treatment, thus, a higher carrier concentration in the CdTe film and higher $\mathrm{V}_{\mathrm{OC}}$ is generated. The complement of $\mathrm{Cu}$ doping concentration also helps to improve all the other $\mathrm{J}-\mathrm{V}$ parameters, including higher $\mathrm{FF}, \mathrm{J}_{\mathrm{SC}}, \mathrm{R}_{\mathrm{SH}}$, and lower $\mathrm{R}_{\mathrm{S}}$, yielding a highest efficiency $16.7 \%$, with $\mathrm{V}_{\mathrm{OC}}$ of $0.857 \mathrm{~V}$, J $\mathrm{SC}$ of $26.2 \mathrm{~mA} / \mathrm{cm}^{2}$, and FF of $74.5 \%$. The detailed information of the best cells with different CuSCN thicknesses are shown in Table 3, and the corresponding J-V curves are shown in Figure S3. As the thickness of CuSCN film increases, PCEs increases from $12.8 \%$ to $16.7 \%$. This improvement can be assigned to two major reasons: first, suggested by significant improvement in FF, the CuSCN film became more uniform and the CdTe film can be fully covered by CuSCN film; second, the $\mathrm{Cu}$ concentration in CdTe increases gradually due to the increase of CuSCN film thickness, and thus, higher $\mathrm{V}_{\mathrm{OC}}$ values can be obtained. When the $\mathrm{CuSCN}$ film thickness is further increased by spin-coating a $10 \mathrm{mg} / \mathrm{mL}$ CuSCN solution at $2000 \mathrm{rpm}, \mathrm{V}_{\mathrm{OC}}$ is further increased to over $0.863 \mathrm{~V}$, but all the other parameters decrease with a J $\mathrm{JSC}_{\mathrm{SC}}$ to $25.3 \mathrm{~mA} / \mathrm{cm}^{2}$, a FF to $70.1 \%$, yielding an efficiency to $15.4 \%$. This is 
likely ascribed to the high resistance of CuSCN film because, taking an example of the same $10 \mathrm{mg} / \mathrm{mL}$ CuSCN solution, decreasing the spin speed from $6000 \mathrm{rpm}$ to $2000 \mathrm{rpm}$ results in increased $R_{\mathrm{S}}$ from 3.43 to $4.17 \Omega \mathrm{cm}^{2}$.
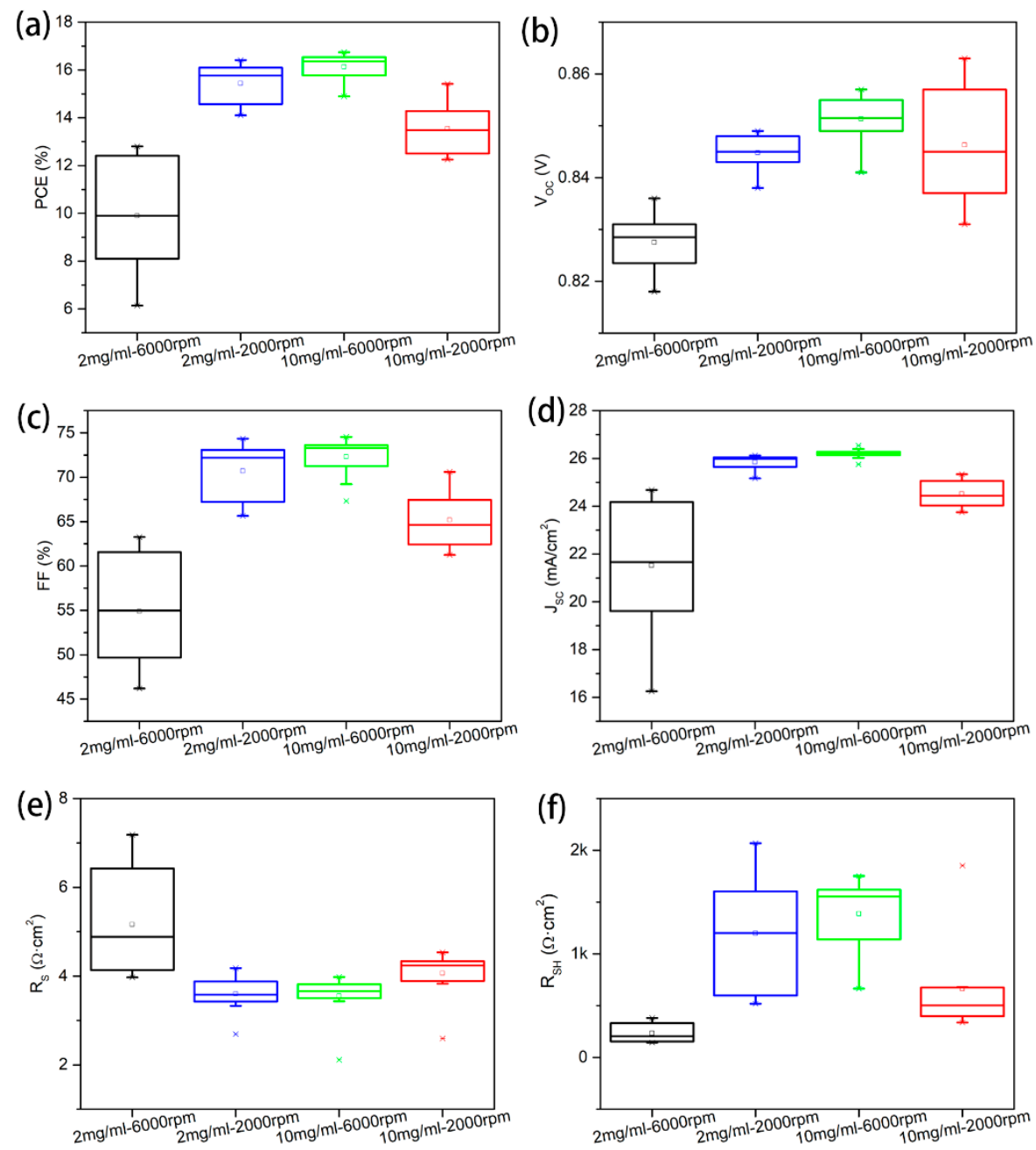

Figure 4. Statistical results for MZO/CdTe solar cell performances of (a) PCE, (b) $\mathrm{V}_{\mathrm{OC}}$, (c) FF, (d) JSC, (e) series resistance $\left(R_{S}\right)$, and (f) shunt resistance $\left(R_{S H}\right)$ with different $\mathrm{CuSCN}$ film thicknesses tuned by varying the solution concentration and the spin-coating speed.

Table 3. The device performance of the best cells with different CdTe-CuSCN thickness.

\begin{tabular}{|c|c|c|c|c|c|c|}
\hline CuSCN Deposition & $\mathrm{V}_{\mathrm{OC}}(\mathrm{V})$ & $\mathrm{JSC}_{\mathrm{SC}}\left(\mathrm{mA} / \mathrm{cm}^{2}\right)$ & FF (\%) & Efficiency (\%) & $R_{S}\left(\Omega \mathrm{cm}^{2}\right)$ & $\mathrm{R}_{\mathrm{SH}}\left(\Omega \mathrm{cm}^{2}\right)$ \\
\hline $2 \mathrm{mg} / \mathrm{mL}-6000 \mathrm{rpm}$ & 0.830 & 24.4 & 63.3 & 12.8 & 4.01 & 381 \\
\hline $2 \mathrm{mg} / \mathrm{mL}-2000 \mathrm{rpm}$ & 0.849 & 26.1 & 74.1 & 16.4 & 3.58 & 2070 \\
\hline $10 \mathrm{mg} / \mathrm{ml}-6000 \mathrm{rpm}$ & 0.857 & 26.2 & 74.5 & 16.7 & 3.43 & 1610 \\
\hline $10 \mathrm{mg} / \mathrm{ml}-2000 \mathrm{rpm}$ & 0.862 & 25.3 & 70.6 & 15.4 & 4.17 & 1350 \\
\hline
\end{tabular}

In order to investigate the origin of device performance improvement with the CuSCN as back contact, the temperature-dependent dark J-V measurements for devices with copper metal $(\mathrm{CdTe}-\mathrm{Cu})$ and $\mathrm{CuSCN}(\mathrm{CuSCN}-160)$ as the back contact were carried out at temperatures ranging from 200 to $310 \mathrm{~K}$, to quantify the back-barrier height as shown in (Figure 5a,b). The temperature dependent dark J-V measurements, as shown in Figure $5 \mathrm{a}, \mathrm{b}$, were carried out at temperatures ranging from 200 to $310 \mathrm{~K}$ to quantify the back-barrier heights of the devices, with $\mathrm{Cu}$ metal and CuSCN as the back contact. For the $\mathrm{CdTe}-\mathrm{Cu}$ device, the J-V curves show a severe roll-over effect at a high forward bias at room temperature, and the roll-over becomes more pronounced as the temperature decreases to 
$200 \mathrm{~K}$. In contrast, the CdTe-CuSCN device shows a typical diode behavior, without roll-over in the temperature range of 310 to $250 \mathrm{~K}$. The presence of roll-over effect indicates the existence of a back barrier at the back interface and thereby enhanced carrier recombination. The values of the back-barrier height for the CdTe-Cu and CdTe-CuSCN are calculated according the reference. [38] As shown in Figure 5c, the CdTe-Cu device exhibits a back-barrier height of $0.662 \mathrm{eV}$, which is extremely high to extract the holes efficiently from the CdTe to the metal electrode. This further explains the origin of low device performances with efficiencies lower than 10\%. The CuSCN-160 device possesses a $0.137 \mathrm{eV}$ back-barrier height, which is much lower than that of the $\mathrm{CdTe}-\mathrm{Cu}$ devices. This small back-barrier height in CuSCN-160 boosts higher carrier extraction efficiency, explaining the origin of the distinctive EQE curves shown in Figure 3b.
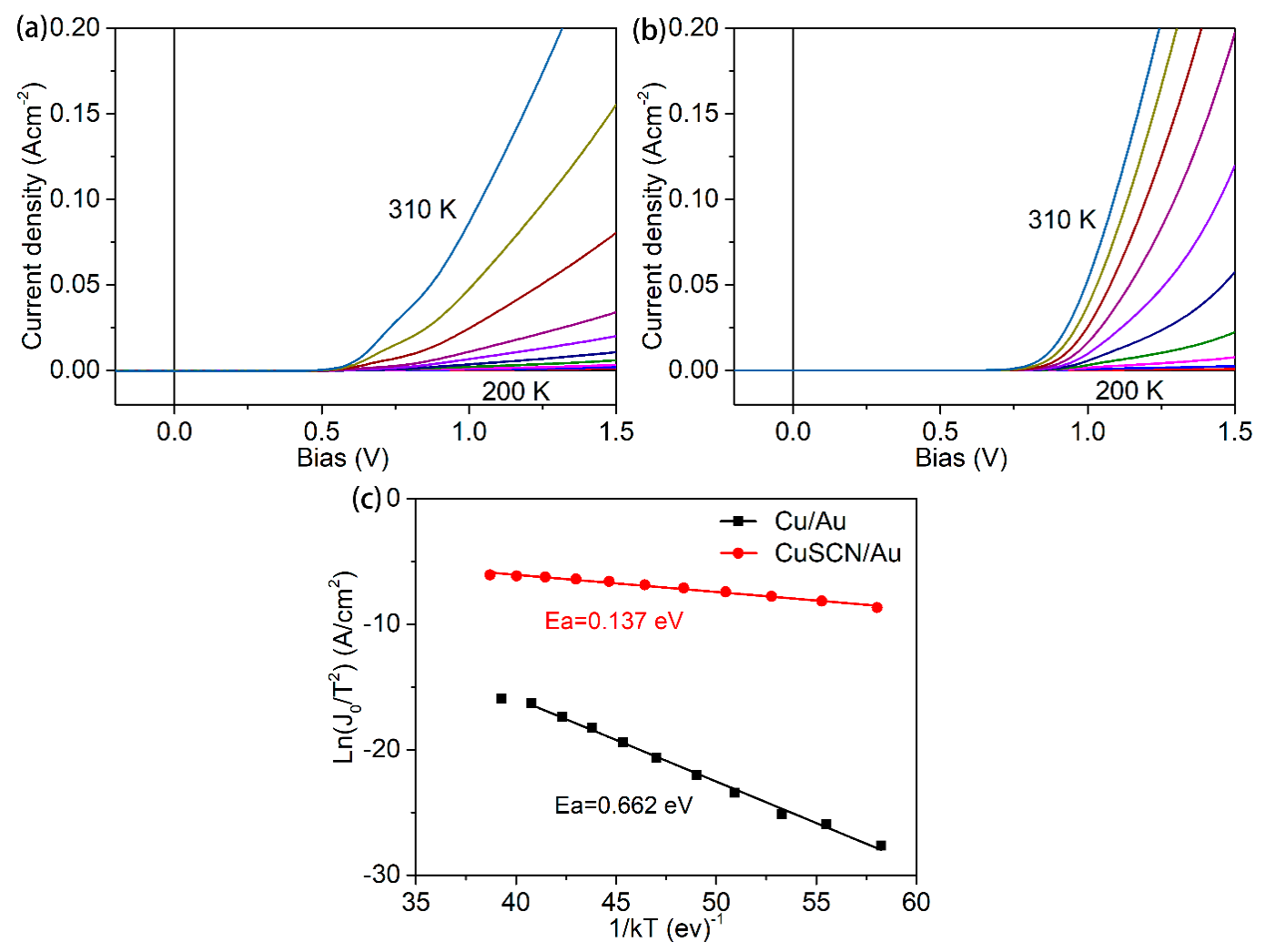

Figure 5. Temperature dependent dark J-V curves for devices with (a) Cu metal and (b) CuSCN as the back contact. (c) Arrhennius plots for the calculation of the back-barrier height for the devices with $\mathrm{Cu}$ metal and CuSCN as the back contact.

Through the careful optimization of the CuSCN treatment, depositing CuSCN film using ammonium hydroxide with water as the solvent was demonstrated to be an efficient means of improving the device performances. However, it has been reported that the performance of $\mathrm{ZMO} / \mathrm{CdTe}$ device degraded gradually while being exposed to ambient conditions, due to the reaction between water in atmosphere and $\mathrm{MgO}$ in ZMO films. [19] To further confirm whether the water in the CuSCN solution will degrade the performance of the $\mathrm{ZMO} / \mathrm{CdTe}$ solar cells during the annealing treatment, a CuSCN solution without water was used for the CuSCN film deposition. Diethyl sulfide has been widely used as the solvent of CuSCN for hole transport layer deposition. [39,40] For the fabrication of the CdTe-CuSCN device with Diethyl sulfide as solvent, the same procedures used for the CuSCN treatment were used. As shown in Figure S4, the devices using CuSCN in ammonium hydroxide show slightly higher and more uniform performances than those using diethyl sulfide as the solvent. This is because that the uniformity of the CuSCN film deposited using ammonium hydroxide solvent is much better than that using diethyl sulfide as the solvent, which has been confirmed in our previous 
report [15]. These results further confirm that the performance of our ZMO/CdTe devices is not affected by the water in ammonium hydroxide, demonstrating a robust hole transport layer deposition procedure for $\mathrm{ZMO} / \mathrm{CdTe}$ solar cells.

\section{Conclusions}

Solution-processed CuSCN treatment with an aqueous solution has been demonstrated to be an efficient procedure for improving the performance of CdTe solar cells with ZMO as the buffer layer. Through the systematic optimization of the CuSCN film thickness and post annealing temperature, the best $\mathrm{ZMO} / \mathrm{CdTe}$ device achieves an efficiency of $16.7 \%$, with a $\mathrm{V}_{\mathrm{OC}}$ of $0.857 \mathrm{~V}$, a J $\mathrm{J}_{\mathrm{SC}}$ of $26.2 \mathrm{~mA} / \mathrm{cm}^{2}$, and an FF of $74.5 \%$. The improvement of the device performance compared with the devices with traditional metallic $\mathrm{Cu}$ is mainly attributed to the significantly reduced back-barrier height from 0.662 to $0.137 \mathrm{eV}$. Our results also indicate that water in ammonium hydroxide solvent has no adverse effect on the $\mathrm{ZMO} / \mathrm{CdTe}$ devices, indicating a high tolerance of the $\mathrm{ZMO} / \mathrm{CdTe}$ devices to humidity, and showing a high flexibility for the post treatment of $\mathrm{ZMO} / \mathrm{CdTe}$ devices in the future.

Supplementary Materials: The following are available online at http://www.mdpi.com/1996-1944/13/8/1991/s1, Figure S1: Cross-sectional SEM images of complete devices with CuSCN as back contact in different magnification, Figure S2: J-V curves the best cells in devices with different CuSCN thickness, Figure S3: Statistical results for MZO/CdTe solar cell performances of (a) PCE, (b) $\mathrm{V}_{\mathrm{OC}},(\mathbf{c}) \mathrm{FF},(\mathrm{d}) \mathrm{JSC}$, (e) series resistance $\left(\mathrm{R}_{\mathrm{S}}\right)$, and (f) shunt resistance $\left(\mathrm{R}_{\mathrm{SH}}\right)$ with different CuSCN solutions, Figure S4: Statistical results for MZO/CdTe solar cell performances of (a) PCE, (b) $\mathrm{V}_{\mathrm{OC}},(\mathbf{c}) \mathrm{FF},(\mathbf{d}) \mathrm{JSC}$, (e) series resistance $\left(\mathrm{R}_{\mathrm{S}}\right)$, and (f) shunt resistance $\left(\mathrm{R}_{\mathrm{SH}}\right)$ with different CuSCN solutions.

Author Contributions: Conceptualization, Y.Y.; methodology, Y.Y.; software, D.-B.L.; validation, F.K.A., R.A.A., N.S., A.B.P., M.J.H., and R.J.E.; formal analysis, D.-B.L.; investigation, D.-B.L., S.S.B. and D.R.; resources, Y.Y.; data curation, D.-B.L.; writing — original draft preparation, D.-B.L.; writing—review and editing, Z.S., N.S., F.Y. and Y.Y.; supervision, Y.Y.; project administration, Y.Y; funding acquisition, Y.Y. and R.E. All authors have read and agreed to the published version of the manuscript.

Funding: This research was funded by Air Force Research Laboratory under agreement number FA9453-18-2-0037, Air Force Research Laboratory, Space Vehicles Directorate under Contract number FA9453-19-C-1002 and the National Science Foundation under contract number 1711534.

Acknowledgments: This material is based on research sponsored by Air Force Research Laboratory under agreement number FA9453-18-2-0037. The US Government is authorized to reproduce and distribute reprints for Governmental purposes notwithstanding any copyright notation thereon. The authors gratefully acknowledge funding support from the U.S. Air Force Research Laboratory, Space Vehicles Directorate, under Contract \# FA9453-19-C-1002. We thank Dr David Strickler from Pilkington North America Inc. for supplying us FTO-coated substrates. The views and conclusions contained herein are those of the authors and should not be interpreted as necessarily representing the official policies or endorsements, either expressed or implied, of Air Force Research Laboratory or the US Government.

Conflicts of Interest: The authors declare no conflict of interest.

\section{References}

1. Green, M.A.; Hishikawa, Y.; Dunlop, E.D.; Levi, D.H.; Hohl-Ebinger, J.; Ho-Baillie, A.W.Y. Solar cell efficiency tables (version 51). Prog. Photovolt. Res. Appl. 2018, 26, 3-12. [CrossRef]

2. NREL Research Cell Record Efficiency Chart. Available online: https://www.nrel.gov/pv/assets/pdfs/pvefficiency-chart.201812171.pdf (accessed on 20 March 2020).

3. Shockley, W.; Queisser, H.J. Detailed balance limit of efficiency of p-n junction solar cells. J. Appl. Phys. 1961, 32, 510-519. [CrossRef]

4. Birkmire, R.W.; Eser, E. Polycrystalline thin film solar cells: Present status and future potential. Annu. Rev. Mater. Sci. 1997, 27, 625-653. [CrossRef]

5. Dharmadasa, I.M.; Alam, A.E.; Ojo, A.A.; Echendu, O.K. Scientific complications and controversies noted in the field of CdS/CdTe thin film solar cells and the way forward for further development. J. Mater. Sci. Mater. Electron. 2019, 30, 20330-20344. [CrossRef]

6. Dobson, K.D.; Visoly-Fisher, I.; Hodes, G.; Cahen, D. Stability of CdTe/CdS thin-film solar cells. Sol. Energ. Mat. Sol. Cell 2000, 62, 295-325. [CrossRef] 
7. McCandless, B.E.; Buchanan, W.A.; Thompson, C.P.; Sriramagiri, G.; Lovelett, R.J.; Duenow, J.; Albin, D.; Jensen, S.; Colegrove, E.; Moseley, J.; et al. Overcoming carrier concentration limits in polycrystalline CdTe thin films with in situ doping. Sci. Rep. 2018, 8, 14519. [CrossRef]

8. Zhao, H.; Farah, A.; Morel, D.; Ferekides, C.S. The effect of impurities on the doping and Voc of CdTe/CdS thin film solar cells. Thin Solid Films 2009, 517, 2365-2369. [CrossRef]

9. Tamotsu, O.; Shigeyuki, I.; Satsuki, N.; Ryoji, H.; Kaoru, Y.; Yohei, K.; Akira, N.; Ryuichi, H. Effects of antimony doping in polycrystalline CdTe thin-film solar cells. Jpn. J. Appl. Phys. 2012, 51, 10NC12.

10. Metzger, W.K.; Grover, S.; Lu, D.; Colegrove, E.; Moseley, J.; Perkins, C.L.; Li, X.; Mallick, R.; Zhang, W.; Malik, R.; et al. Exceeding 20\% efficiency with in situ group V doping in polycrystalline CdTe solar cells. Nat. Energy 2019, 4, 837-845. [CrossRef]

11. Paudel, N.R.; Yan, Y. Application of copper thiocyanate for high open-circuit voltages of CdTe solar cells. Prog. Photovolt. Res. Appl. 2016, 24, 94-101. [CrossRef]

12. Kumara, G.R.R.A.; Konno, A.; Senadeera, G.K.R.; Jayaweera, P.V.V.; De Silva, D.B.R.A.; Tennakone, K. Dye-sensitized solar cell with the hole collector p-CuSCN deposited from a solution in n-propyl sulphide. Sol. Energ. Mat. Sol. Cell 2001, 69, 195-199. [CrossRef]

13. Lévy-Clément, C.; Tena-Zaera, R.; Ryan, M.A.; Katty, A.; Hodes, G. CdSe-sensitized p-CuSCN/nanowire n-ZnO heterojunctions. Adv. Mater. 2005, 17, 1512-1515. [CrossRef]

14. Arora, N.; Dar, M.I.; Hinderhofer, A.; Pellet, N.; Schreiber, F.; Zakeeruddin, S.M.; Grätzel, M. Perovskite solar cells with CuSCN hole extraction layers yield stabilized efficiencies greater than $20 \%$. Science 2017, 358, 768-771. [CrossRef] [PubMed]

15. Montgomery, A.; Guo, L.; Grice, C.; Awni, R.A.; Saurav, S.; Li, L.; Yan, Y.; Yan, F. Solution-processed copper (i) thiocyanate $(\mathrm{CuSCN})$ for highly efficient CdSe/CdTe thin-film solar cells. Prog. Photovolt. Res. Appl. 2019, 27, 665-672. [CrossRef]

16. Ablekim, T.; Colegrove, E.; Metzger, W.K. Interface engineering for $25 \%$ CdTe solar cells. ACS Appl. Energy Mater. 2018, 1, 5135-5139. [CrossRef]

17. Munshi, A.H.; Kephart, J.; Abbas, A.; Raguse, J.; Beaudry, J.; Barth, K.; Sites, J.; Walls, J.; Sampath, W. Polycrystalline CdSeTe/CdTe absorber cells with $28 \mathrm{~mA} / \mathrm{cm}^{2}$ short-circuit current. IEEE J. Photovolt. 2018, 8, 310-314. [CrossRef]

18. Li, D.-B.; Song, Z.; Awni, R.A.; Bista, S.S.; Shrestha, N.; Grice, C.R.; Chen, L.; Liyanage, G.K.; Razooqi, M.A.; Phillips, A.B.; et al. Eliminating s-kink to maximize the performance of $\mathrm{MgZnO} / \mathrm{CdTe}$ solar cells. ACS Appl. Energy Mater. 2019, 2, 2896-2903. [CrossRef]

19. Ablekim, T.; Perkins, C.; Zheng, X.; Reich, C.; Swanson, D.; Colegrove, E.; Duenow, J.N.; Albin, D.; Nanayakkara, S.; Reese, M.O.; et al. Tailoring MgZnO/CdSeTe interfaces for photovoltaics. IEEE J. Photovolt. 2019, 9, 888-892. [CrossRef]

20. Bittau, F.; Jagdale, S.; Potamialis, C.; Bowers, J.W.; Walls, J.M.; Munshi, A.H.; Barth, K.L.; Sampath, W.S. Degradation of Mg-doped zinc oxide buffer layers in thin film CdTe solar cells. Thin Solid Films 2019, 691, 137556. [CrossRef]

21. Paudel, N.R.; Xiao, C.; Yan, Y. Close-space sublimation grown CdS window layers for CdS/CdTe thin-film solar cells. J. Mater. Sci. Mater. Electron. 2014, 25, 1991-1998. [CrossRef]

22. Kuribayashi, K.; Matsumoto, H.; Uda, H.; Komatsu, Y.; Nakano, A.; Ikegami, S. Preparation of low resistance contact electrode in screen printed CdS/CdTe solar cell. Jpn. J. Appl. Phys. 1983, 22, 1828-1831. [CrossRef]

23. Awni, R.A.; Li, D.-B.; Grice, C.R.; Song, Z.; Razooqi, M.A.; Phillips, A.B.; Bista, S.S.; Roland, P.J.; Alfadhili, F.K.; Ellingson, R.J.; et al. The effects of hydrogen iodide back surface treatment on CdTe solar cells. Solar RRL 2019, 3, 1800304. [CrossRef]

24. Bätzner, D.L.; Wendt, R.; Romeo, A.; Zogg, H.; Tiwari, A.N. A study of the back contacts on CdTe/CdS solar cells. Thin Solid Films 2000, 361-362, 463-467. [CrossRef]

25. Watthage, S.C.; Phillips, A.B.; Liyanage, G.K.; Song, Z.; Gibbs, J.M.; Alfadhili, F.K.; Alkhayat, R.B.; Ahangharnejhad, R.H.; Almutawah, Z.S.; Bhandari, K.P.; et al. Selective Cd removal from CdTe for high-efficiency Te back-contact formation. IEEE J. Photovolt. 2018, 8, 1125-1131. [CrossRef]

26. Burgelman, M.; Nollet, P.; Degrave, S. Modelling polycrystalline semiconductor solar cells. Thin Solid Films 2000, 361-362, 527-532. [CrossRef]

27. Jaffe, J.E.; Kaspar, T.C.; Droubay, T.C.; Varga, T.; Bowden, M.E.; Exarhos, G.J. Electronic and defect structures of CuSCN. J. Phys. Chem. C 2010, 114, 9111-9117. [CrossRef] 
28. Hausmann, A.; Schallenberger, B.; Roll, R. A new model for ZnO:Cu undergoing dynamic Jahn-Teller coupling. Z. Phys. B 1980, 40,1-7. [CrossRef]

29. Kutty, T.R.N.; Raghu, N. Varistors based on polycrystalline ZnO:Cu. Appl. Phys. Lett. 1989, 54, 1796-1798. [CrossRef]

30. Xu, C.X.; Sun, X.W.; Zhang, X.H.; Ke, L.; Chua, S.J. Photoluminescent properties of copper-doped zinc oxide nanowires. Nanotechnology 2004, 15, 856-861. [CrossRef]

31. Biglari, B.; Samimi, M.; Hage-Ali, M.; Koebel, J.M.; Siffert, P. Effects of copper in high resistivity cadmium telluride. J. Cryst. Growth 1988, 89, 428-434. [CrossRef]

32. Jones, E.D.; Stewart, N.M.; Mullin, J.B. The diffusion of copper in cadmium telluride. J. Cryst. Growth 1992, 117, 244-248. [CrossRef]

33. Yan, Y.; Jones, K.; Zhou, J.; Wu, X.; Al-Jassim, M. Tem study of locations of Cu in CdTe solar cells. MRS Proc. 2011, 1012. [CrossRef]

34. Demtsu, S.H.; Sites, J.R. Effect of back-contact barrier on thin-film CdTe solar cells. Thin Solid Films 2006, 510, 320-324. [CrossRef]

35. Burgelman, M.; Verschraegen, J.; Degrave, S.; Nollet, P. Analysis of CdTe solar cells in relation to materials issues. Thin Solid Films 2005, 480-481, 392-398. [CrossRef]

36. Awni, R.A.; Li, D.-B.; Song, Z.; Bista, S.S.; Razooqi, M.A.; Grice, C.R.; Chen, L.; Liyanage, G.K.; Li, C.; Phillips, A.B.; et al. Influences of buffer material and fabrication atmosphere on the electrical properties of CdTe solar cells. Prog. Photovolt. Res. Appl. 2019, 27, 1115-1123. [CrossRef]

37. Corwine, C.R.; Pudov, A.O.; Gloeckler, M.; Demtsu, S.H.; Sites, J.R. Copper inclusion and migration from the back contact in CdTe solar cells. Sol. Energy Mat. Sol. Cell 2004, 82, 481-489. [CrossRef]

38. Li, J.V.; Johnston, S.W.; Li, X.; Albin, D.S.; Gessert, T.A.; Levi, D.H. Discussion of some "trap signatures" observed by admittance spectroscopy in CdTe thin-film solar cells. J. Appl. Phys. 2010, 108, 64501. [CrossRef]

39. Chaudhary, N.; Chaudhary, R.; Kesari, J.P.; Patra, A.; Chand, S. Copper thiocyanate (CuSCN): An efficient solution-processable hole transporting layer in organic solar cells. J. Mater. Chem. C 2015, 3, 11886-11892. [CrossRef]

40. Madhavan, V.E.; Zimmermann, I.; Roldán-Carmona, C.; Grancini, G.; Buffiere, M.; Belaidi, A.; Nazeeruddin, M.K. Copper thiocyanate inorganic hole-transporting material for high-efficiency perovskite solar cells. ACS Energy Lett. 2016, 1, 1112-1117. [CrossRef] 